\title{
AN ASSESSMENT OF CAPACITY OF BRESTOVICA - KLARIČI KARST WATER SUPPLY (SLOVENIA)
}

\section{OCENA IZDATNOSTI VODNEGA VIRA BRESTOVICA - KLARIČI (SLOVENIJA)}

\author{
Janko URBANC ${ }^{1}$, Kim MEZGA $^{1 *}$ \& Luca ZINI ${ }^{2}$
}

\begin{abstract}
UDC 556.3:628.1(497.472)

Janko Urbanc, Kim Mezga \& Luca Zini: An assessment of capacity of Brestovica - Klariči karst water supply (Slovenia)

In August 2008 an intensive pumping experiment was carried out in order to assess the capacity of Brestovica - Klariči water supply in summer conditions, and its chemical quality. Groundwater was pumped for a period of 30 days, from three wells at the Klariči pumping station, and from well B-10/06, with a common capacity of $470 \mathrm{~L} / \mathrm{s}$. The fact that pumping caused a decrease in the water table in well B-10/06 by only $17 \mathrm{~cm}$ at a pumping rate of $265 \mathrm{~L} / \mathrm{s}$ suggests that larger quantities of groundwater could be pumped from this well. The tracer experiment, performed at the B-10/06 temporary pipe line discharge area, showed that no pumped water was returned to the area of the exploited wells during the pumping test. Tracer uranine, which had been injected at the effluent from the pumped water from the well, was detected only at the Sardos Spring. The intensive pumping resulted in changes in the chemical and isotopic composition of oxygen in the water, due to a greater impact of the water from the intergranular Soča River aquifer on the karst aquifer. The chemical quality of groundwater from well B-10/06 is adequate for the purpose of drinking water supply. The presence of bacteria in groundwater is typical of karst aquifers and the water needs to be disinfected for further use. Keywords: groundwater, Classical Karst, Brestovica - Klariči aquifer, pumping test, tracer test, geochemical analysis.
\end{abstract}

Izvleček

UDK 556.3:628.1(497.472)

Janko Urbanc, Kim Mezga \& Luca Zini: Ocena izdatnosti vodnega vira Brestovica - Klariči (Slovenija)

V avgustu 2008 je bil na vodnem viru Brestovica - Klariči opravljen črpalni poizkus, katerega namen je bil ugotoviti kapaciteto in kemijsko sestavo vodnega vira ob intenzivnem črpanju v poletnem času. Intenzivno črpanje iz vodonosnika je trajalo 30 dni, skupna količina 470 l/s je bila črpana iz obstoječih vodnjakov črpališča Klariči ter iz novega vodnjaka B-10/06. Ob črpanju $265 \mathrm{l} / \mathrm{s}$ se je nivo podzemne vode $\mathrm{v}$ vodnjaku B-10/06 znižal le za $17 \mathrm{~cm}$, kar kaže, da bi bilo na tem področju možno izkoriščati še večjo količino podzemne vode. Sledilni poizkus, ki je bil izveden na iztoku iz začasnega odvodnjevalnega cevovoda iz vodnjaka B-10/06, je pokazal, da ne prihaja do vračanja izčrpane vode nazaj na območje črpališča. Sledilo uranin se je pojavilo le v izviru Sardoč, ki predstavlja enega od iztokov kraškega izvira Timav. Intenzivno črpanje iz vodonosnika se je odrazilo v spremembah kemijske in izotopske sestave podzemne vode, ki so nastale zaradi večjega deleža podzemne vode, ki izhaja iz medzrnskega vodonosnika reke Soče. Kemijske značilnosti izčrpane vode ustrezajo kriterijem za pitno vodo, razen prisotnosti bakterij, ki so značilne za kraške vode. Zaradi občasne prisotnosti bakterij je na vodovodnem sistemu potrebna predhodna dezinfekcija vode. Ključne besede: podzemna voda, Kras, vodonosnik Brestovica - Klariči, črpalni poizkus, sledilni poizkus, geokemijska analiza.

\footnotetext{
${ }^{1}$ Geological Survey of Slovenia, Dimičeva ulica 14, SI-1000 Ljubljana, Slovenia, e-mail: janko.urbanc@geo-zs.si

${ }^{1 *}$ Geological Survey of Slovenia, Dimičeva ulica 14, SI-1000 Ljubljana, Slovenia, e-mail: kim.mezga@geo-zs.si, tel: +3861 2809 818, fax: +38612809753

${ }^{2}$ Department of Geosciences of the University of Trieste, Via E. Weiss 2, IT-34127 Trieste, Italy, e-mail: zini@units.it
}

Received/Prejeto: 26.4.2011 


\section{INTRODUCTION}

Obtaining a supply of sufficient bacteriologically and chemically safe drinking water to the Classical Karst inhabitants of the Slovene Classical Karst region has always been a problem in southwestern part of Slovenia (Fig. 1). Therefore the Brestovica karst aquifer has been a constant target of much research from the middle 1970s till the early 1990s of the previous century. It was found that the Brestovica aquifer is a rich water source that could provide much needed drinking water to the Karst and Slovenian Coast population. The pumping station Klariči was constructed in 1985 and is located in the north-western part of Slovenia, $2 \mathrm{~km}$ west of the village Brestovica (Krivic 1983; Krivic et al. 1985; Krivic et al. 1986). Three pumping wells were constructed at the pumping station area with a common capacity of about 250 L/s. Krivic (1983) anticipated that from the Brestovica - Klariči water supply more than $1,000 \mathrm{~L} / \mathrm{s}$ of water could be extracted.

Because of increased population and economic growth the needs for karst aquifer exploitation for effective and sustainable use of drinking water have increased. It was necessary to evaluate whether the Brestovica -
Klariči water supply could provide water to the Coastal area during the low Rižana Spring discharge. The Rižana Spring is of karst type and its capacity is occasionally significantly reduced, especially during the summer, when dry periods are quite common. The results obtained would serve as a basis for the decision regarding the Slovenian Coastal area water supply strategy.

A new pumping well B-10/06 was constructed in the year 2006 to increase Brestovica - Klariči water supply potential. In order to test the actual efficiency of well B-10/06 in combination with three existing pumping wells in summer conditions, an extended pumping test was carried out in summer 2008. During the pumping test groundwater was simultaneously pumped from three wells at the Klariči pumping station and from well B-10/06. The study also includes an interpretation of changes in chemical composition and ${ }^{18} \mathrm{O}$ isotope composition of sampled water and a tracer experiment during the pumping test, which complements previous hydrogeological investigations performed in this area (Urbanc \& Kristan 1998; Doctor et al. 2006).

\section{CHARACTERISTICS OF THE STUDY AREA}

The Classical Karst aquifer Brestovica (Fig. 1) is a part of the Dinaric Trieste-Komen Karst, located in the south-

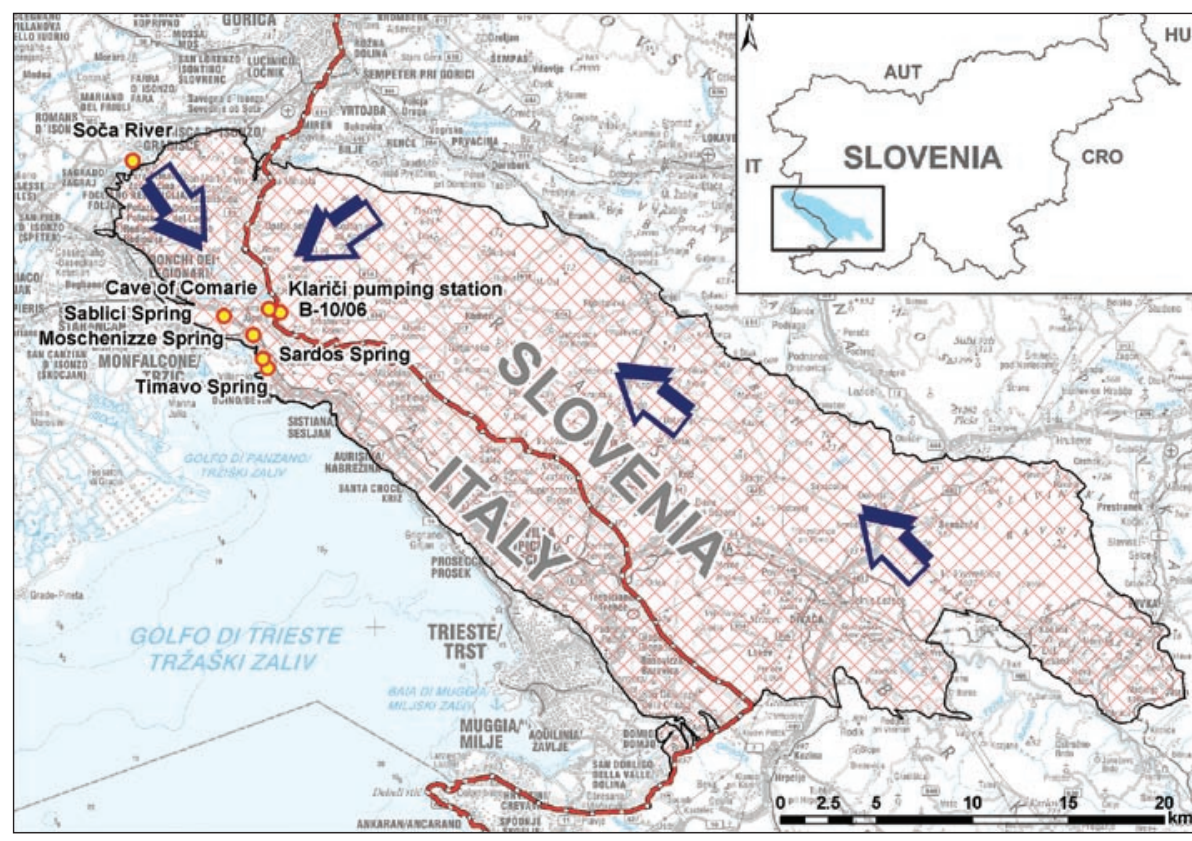

Fig. 1: The location of karst aquifer Brestovica, sampling points and direction of groundwater flow. western part of Slovenia. The trans-boundary aquifer extends from Vremščica in the southeast, over Dutovlje and Komen in the east and Kostanjevica in the north, crossing the Italian border close to Doberdó (Doberdob) and Gradisca d'Isonzo (Gradišče) and, in the south, from Basovizza (Bazovica) to Duino (Devin). Due to the dissolution of carbonate rocks that constitute the aquifer, various karst phenomena have developed (barren karst areas, dolinas, caves, deep shafts, etc.). The surface is formed by hills with gentle elevations reaching an average elevation of 250-300 $\mathrm{m}$ a.s.l. with the top at Trstelj Hill $(643 \mathrm{~m})$. The aquifer is quite large with an area of about $750 \mathrm{~km}^{2}$. It is built primarily of intensively karstified highly permeable 
limestones and dolomites of Cretaceous and Paleogene age (Cucchi \& Zini 2002a; Jurkovšek 2008, 2010).

In the north and northeast of the aquifer, carbonate rocks are in contact with layers of Eocene flysch of low permeability from the Vipava Valley to the Trstelj Hill. In the flysch sequence sandstone, siltstone, claystone and marl are found. In the southwest the aquifer is in contact with Eocene flysch beds at the Gulf of Trieste, and in the west and southwest with alluvial deposits of the Soča River. From the geotectonic point of view, the Brestovica aquifer belongs to External Dinarides as the southwestern part of the Trieste-Komen anticlinorium which is built from larger and smaller folds. The Brestovica anticlinorium is cored with dolomite near the east-west trending Brestovica fault, which is the most important structure in this research area. Important faults having a typical Dinaric orientation (northwest-southeast) in this region are the Raša and Divača faults (Jurkovšek 2008, 2010), and the Palmanova-Črni Kal line (Carulli 2011).

The vadose zone of the aquifer at Klariči pumping station is around $20 \mathrm{~m}$ thick. With distance from the pumping station to the northeast of the aquifer the unsaturated zone is getting thicker, reaching up to $150 \mathrm{~m}$ at Pliskovica (Urbanc et al. 2007). Cretaceous limestones around the pumping station Klariči are karstified and create an aquifer with karstic channels, through which the groundwater flows. The main karstic channels are located at depths between 53 and $70 \mathrm{~m}$ below the ground level and present the boundary between the bedded limestone of the Povir formation and the one of Brje formation (Urbanc et al. 2007; Jurkovšek 2008, 2010). Data obtained by flowmeter in borehole $\mathrm{Br}-8$, situated in the vicinity ofwell B-10/06, suggest that the main groundwater flow to the borehole occurs at the depth between 55 and $60 \mathrm{~m}$ below the ground level (Urbanc et al. 2007). Krivic et al. (1985) estimated the apparent aquifer transmissivity in the area around Klariči pumping station between $7 \times 10^{-2}$ and $8 \times 10^{-1} \mathrm{~m}^{2} / \mathrm{s}$ with an effective porosity between $3-4 \%$.

The aquifer is recharged autogenically from local precipitation with an average yearly precipitation rate of $1,480 \mathrm{~mm}$ (Bat et al. 2008), and an average yearly evapotranspiration of $530 \mathrm{~mm}$, so the effective precipitation, which actually recharges the aquifer, is about $760 \mathrm{~mm}$. The mean values of evapotranspiration and effective precipitation were obtained by the Kennessey methodology (Prestor \& Janža 2006). Although there are practically no surface streams directly above Brestovica aquifer, the aquifer is also recharged by allogenic water derived from sinking rivers and streams (the Raša and Reka Rivers, the Sajevče and Senožeče Brooks, and the streams from $\mathrm{Br}$ kini Hills) and losses from the Soča and Vipava Rivers.

In the eastern part of the aquifer the groundwater flow is oriented towards the northwest and in the west- ern part of the aquifer, near the Italian border, the flow direction changes to the southwest towards the Timavo Spring (Civita et al. 1995). It has been suggested by numerous authors (Boegan 1938; Krivic et al. 1986; Pezdič et al. 1986; Flora \& Longinelli 1989; Urbanc \& Kristan 1998; Doctor et al. 2000; Cucchi \& Zini 2002b; Doctor 2008) that water from the Soča and Vipava Rivers also contribute to this aquifer's groundwater. Urbanc and Kristan (1998) confirmed that aquifer recharge in the area of pumping station Klariči depends on changing seasonal hydrologic conditions during pumping. In the rainy season the aquifer is mainly recharged from the Slovene karstic area, but during summer dry periods, when the hydraulic pressure of the karst aquifer decreases, as much as $50-60 \%$ of the aquifer's water is fed by the water from the intergranular aquifer of the Soča River. Similar observations were also made using deuterium and carbon-13 isotope composition of groundwater in samples collected at pumping station Klariči (Doctor et al. 2000; Doctor et al. 2006). The approximate transit time of water from the intergranular Soča River aquifer to the wells of pumping station Klariči is estimated to be around 2 months (Doctor 2008). Since the Soča River flows on a thick alluvial deposit, a clearly identifiable sinking point cannot be precisely located (Bidovec 1967). Losses of around $10 \mathrm{~m}^{3} / \mathrm{s}$ from the Soča River have been measured along $12 \mathrm{~km}$ of the river's course between the towns of Gorizia (Gorica) and Gradisca d'Isonzo (Gradišče) (Mosetti \& D’Ambrosi 1963; ACEGA Trieste 1988; Zini et al. 2011). Measurements of piezometric water levels in the alluvial aquifer surrounding the Soča River indicate an area of focused groundwater loss between the river and the elevated Kras plateau (Mosetti \& D'Ambrosi 1963). Both recharge components are mixed within the aquifer and are discharged in the Timavo Spring group and in submarine springs on the Italian side west of Aurisina (Nabrežina) (Civita et al. 1995).

The pumping facility Klariči (Fig. 2) consists of three $70 \mathrm{~m}$ deep wells (VB-4/79, VB-4/80 and VB-4/81)

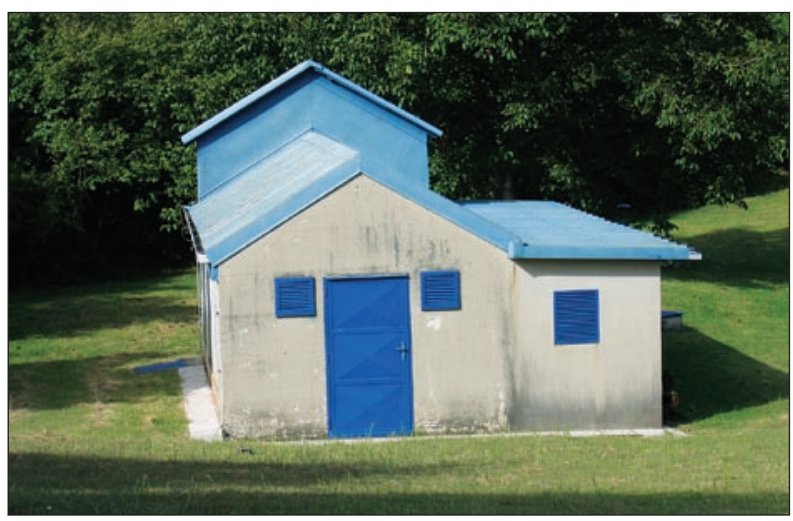

Fig. 2: Pumping station Klariči (Photo: K. Mezga). 
with diameters of 400 and $500 \mathrm{~mm}$ and a total capacity of $250 \mathrm{~L} / \mathrm{s}$. After many pumping tests in the period from 1976 to 1979, a potential estimated capacity of over $1,000 \mathrm{~L} / \mathrm{s}$ of groundwater was estimated for the Brestovica - Klariči aquifer (Krivic 1983). To define the direction of groundwater flow five $50 \mathrm{~m}$ deep piezometers were drilled (in 1985) in a 100-120 m radius around the pumping station Klariči. During years 2006-2007 further intensive hydrogeological research took place, where three additional $150 \mathrm{~m}$ deep piezometers $(\mathrm{Br}-6, \mathrm{Br}-7$ and $\mathrm{Br}-8)$ and a new well B-10/06 with $600 \mathrm{~mm}$ diameter and $80 \mathrm{~m}$ depth were drilled (Urbanc et al. 2007, 2008).

The pumping station Klariči is part of the Karst water supply system Kraški vodovod Sežana, providing drinking water to five Karst communities (Miren - Ko- stanjevica, Komen, Sežana, Divača, and Hrpelje - Kozina) and during summer months to the Slovenian Coastal region as well. Pumped water flows through pipelines to the water filtration and disinfection facility Sela na Krasu and is further distributed to reservoir Lipa under the Trstelj Hill. The water supply network system continues towards Kostanjevica and Opatje selo on one side and towards Komen, Dutovlje, Križ and Sežana on the other. Later the section Sežana-Rodik-Kozina was attached, which serves for additional water supply of the Slovenian Coast (Ravbar 2004). Usually around $100 \mathrm{~L} / \mathrm{s}$ are pumped for the Karst area water demand, however, when simultaneously supplying the Coastal area, around $200 \mathrm{~L} / \mathrm{s}$ are extracted (Kristan \& Skrinjar 1998).

\section{METHODS}

The pumping test was carried out during the 30-day summer period in August 2008. Groundwater was simultaneously pumped from well B-10/06 and all three wells at pumping station Klariči. The reduced amount of precipitation and intensive vegetation growth decreased the infiltration of meteoric water, which resulted in a lower groundwater table. Detailed observations of groundwater characteristics during intense pumping were performed; groundwater level, temperature and electrical conductivity were observed, and sampling for chemical and isotopic analyses was done at the same time. Through the tracer experiment, eventual reflux from discharged groundwater to the pumping area could be identified. The amount of precipitation was measured continuously with an electronic rain gauge equipped with data logger, which was approximately $48 \mathrm{~m}$ distant from well B-10/06.

\section{PUMPING TEST}

A $180 \mathrm{~kW}$ submersible pump Pleuger KN303-3 with a capacity of $100-290 \mathrm{~L} / \mathrm{s}$ was installed in the $80 \mathrm{~m}$ deep well B-10/06 (Fig. 3) at $38 \mathrm{~m}$ below ground level. The water table, temperature and electrical conductivity measurements of groundwater, which were taken every 10 minutes, were performed by automatic probe MK-100 (Eltratec d.o.o., Slovenia), placed approximately $10 \mathrm{~m}$ below the pump. The two probes for electrical conductivity and groundwater level were connected to Eltratec data logger MRE 300. Data were sent to the server over the GPRS network. Since the well is located $4 \mathrm{~km}$ north of the Adriatic Coast, the measurement system would trigger an alarm in case the groundwater electrical conductivity exceeded the predefined threshold of $800 \mu \mathrm{S} / \mathrm{cm}$.
The pumping experiment in duration of one month was performed in well B-10/06, from which groundwater was pumped continuously at a rate of $265 \mathrm{~L} / \mathrm{s}$. At the same time groundwater was also pumped from all three exploitation wells at the Klariči pumping station. Except for the two short breaks at the beginning of the experiment at Klariči, the exploitation wells pumped continuously a total of $206 \mathrm{~L} / \mathrm{s}$ of groundwater. Water pumped

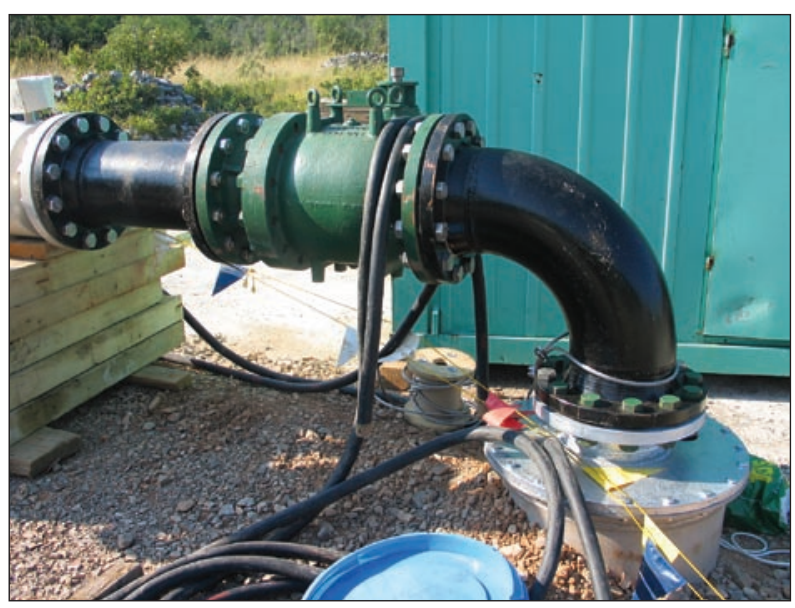

Fig. 3: Well B-10/06 connected to temporary pipeline (Photo: K. Mezga).

from well B-10/06 was discharged through a temporary pipeline (Fig. 4) located outside the zone of influence of the pumping wells. Temporary pipeline had a diameter of $500 \mathrm{~mm}$ and a length of $700 \mathrm{~m}$. The route of the temporary pipeline was in the southeast direction from 


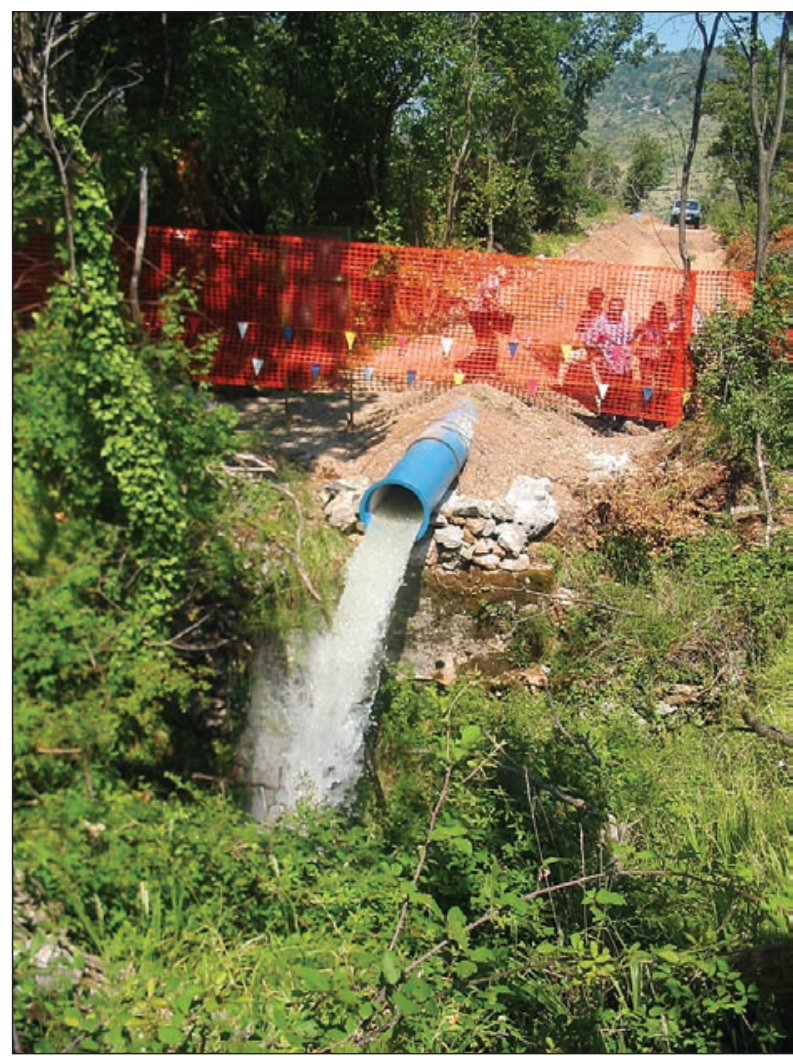

Fig. 4: Pumped groundwater from well B-10/06 discharged through a temporary pipeline (Photo: J. Urbanc).

well B-10/06 with $60 \mathrm{~m}$ of elevation difference (Fig. 5). The pipeline was directed towards a small cavern which

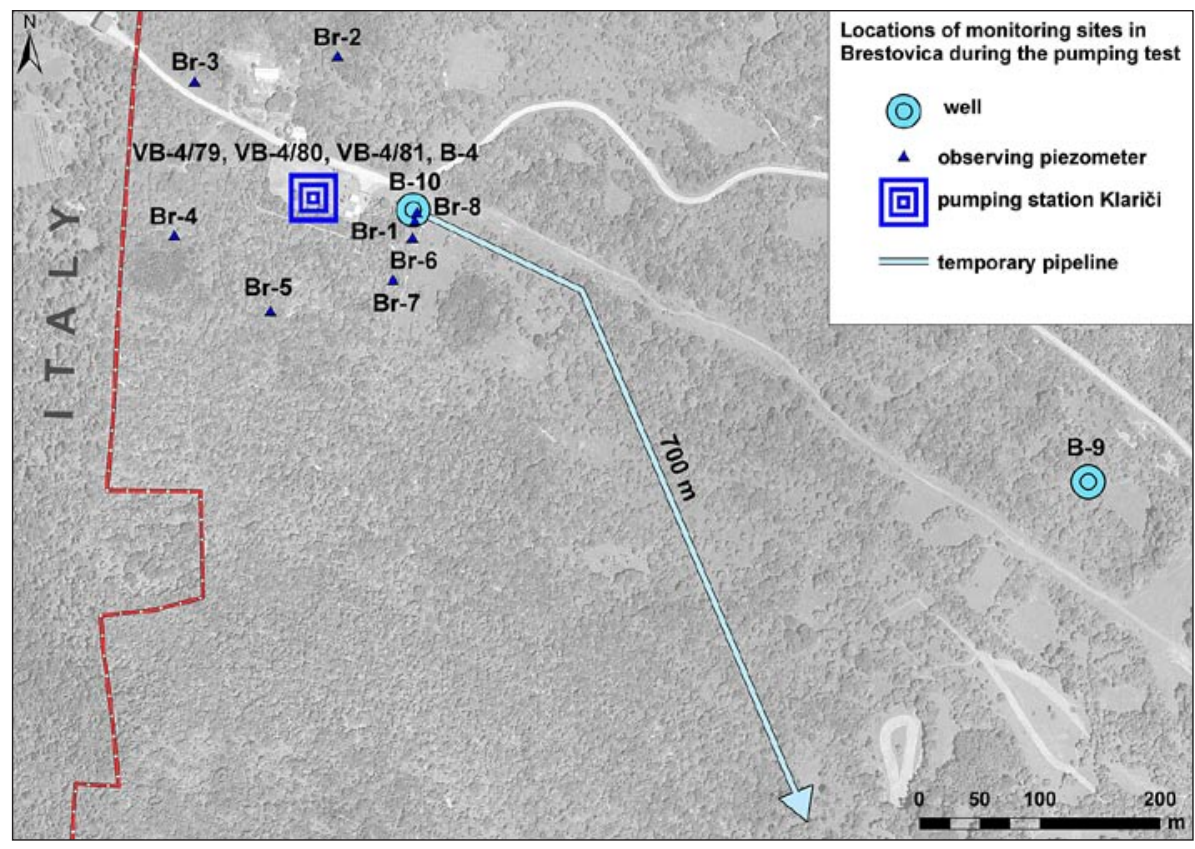

Fig. 5: Map of monitoring site locations and the temporary pipeline in the area around the Klariči pumping station during the pumping test. is filled with collapsed material. Water from exploitation wells at the pumping station Klariči was discarded via the existing water supply network. The excess of pumped water in the water system was discharged at Rodik near Kozina.

At the end of the pumping test a step-drawdown test was carried out in well B-10/06 to determine the changes of groundwater level at different pumping rates. For this experiment five different pumping rates were used (50, $100,151,201$ and $265 \mathrm{~L} / \mathrm{s}$ ), each quantity being pumped for about 15 minutes.

During intensive pumping, detailed observations were performed also on monitoring objects in the vicinity of well B-10/06. Groundwater level, temperature and electrical conductivity were continuously measured by automatic data loggers Eltratec in 3 pumping wells (VB$4 / 79, \mathrm{VB}-4 / 80$ and $\mathrm{VB}-4 / 81)$ and 10 piezometers (B-4, $\mathrm{B}-9, \mathrm{Br}-1, \mathrm{Br}-2, \mathrm{Br}-3, \mathrm{Br}-4, \mathrm{Br}-5, \mathrm{Br}-6, \mathrm{Br}-7$ and $\mathrm{Br}-8)$, all of them located within 400-m radius of well B-10/06 (Fig. 5). Groundwater level was occasionally also measured manually by electric water level meter.

\section{TRACER TEST}

$100 \mathrm{~g}$ of fluorescent dye uranine was dissolved in $10 \mathrm{~L}$ of water and injected (Fig. 6) into the cavern at the discharge end of the temporary pipeline. In order to detect a possible uranine breakthrough in the groundwater, three automatic fluorimeters (FFUN-FL) were installed in piezometer B-4 (Slovenia), at Sardos Spring (Italy) and at Cave of Comarie (Italy). Measurements were taken simultaneously every 15 minutes. Samples of groundwater from pumping well B-10/06, the Timavo Spring, the Moschenizze Spring and the Sardos Spring were also taken every day (August $4^{\text {th }}$ $25^{\text {th }}$ ) for laboratory analysis. Water samples (a total of 73 water samples) were analysed for fluorescence in the laboratory of public utility Vodovod-Kanalizacija d.o.o., Slovenia. Standard practice for the identification of chemicals in water by fluorescence spectroscopy with accredited status according to SIST EN ISO/IEC 17025 (certificate No. LP-023) was used; the measurements were taken by Shimadzu RF-1501 spectrofluorimeter. The limit 
of determination of uranine in groundwater (LOQ) was $0.033 \mu \mathrm{g} / \mathrm{L}$, and the limit of detection (LOD) $0.010 \mu \mathrm{g} / \mathrm{L}$.

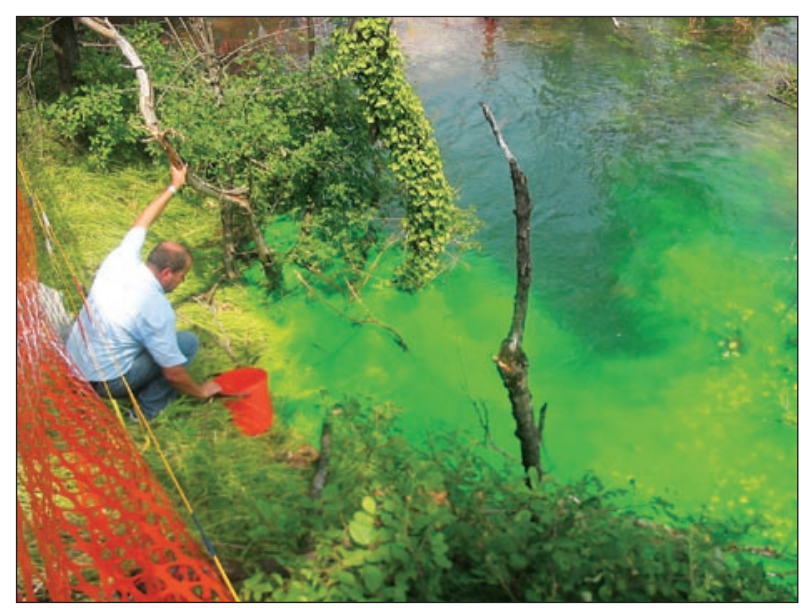

Fig. 6: Injection of the tracer fluorescent dye uranine (Photo: K. Mezga).

\section{WATER SAMPLING FOR HYDROCHEMICAL, ISOTOPIC AND BACTERIOLOGICAL}

\section{ANALYSES}

Water samples for hydrochemical, isotopic and bacteriological analyses were taken during the pumping test. Water from wells B-10/06 and B-9, the Timavo Spring and the Soča River (at Gradiscad'Isonzo / Gradišče) was taken approximately every 5 days for hydrochemical and isotopic analysis. Basic hydrochemical parameters $(\mathrm{pH}$, electrical conductivity, $\mathrm{HCO}_{3}^{-}, \mathrm{Cl}^{-}, \mathrm{Ca}^{2+}, \mathrm{Mg}^{2+}, \mathrm{Na}^{+}, \mathrm{K}^{+}$, $\mathrm{NO}_{3}^{-}$and $\mathrm{SO}_{4}^{2-}$ ) were analyzed in the laboratory of public utility Vodovod-Kanalizacija d.o.o. in Ljubljana. The analysis of stable isotope oxygen- $18\left(\delta^{18} \mathrm{O}\right)$ in water was performed by Hydroisotop $\mathrm{GmbH}$, Germany. Oxygen -18 in the water was determined by the $\mathrm{CO}_{2}$ equilibration technique. A water sample from well B-10/06 was taken also for drinking water quality analysis during the pumping experiment, performed at the laboratories of the Institutes of Public Health Koper, Novo mesto and Nova Gorica.

\section{RESULTS AND DISCUSSION}

Rainfall measurements showed that during the pumping test a total of $163.2 \mathrm{~L} / \mathrm{m}^{2}$ of rain occurred, mostly in the form of summer storms which drained fast and had no intensive long-term influence on water quantity in the aquifer. The groundwater level was for the most part at the base flow level, except after three storms during the first period of the test. Based on this data it can be concluded that the pumping test was carried out in typical summerclimate conditions.

\section{PUMPING TEST}

The discharged pumped water from the temporary pipeline first filled the cavern (in $12 \mathrm{~min}$ ), and later the superfluous water drained to a near dolina, forming a temporary lake (Fig. 7). During the pumping test a total of $559000 \mathrm{~m}^{3}$ of groundwater from the exploitation wells in Klariči, and a total of $712400 \mathrm{~m}^{3}$ from well B-10/06 was pumped. With a common capacity of $470 \mathrm{~L} / \mathrm{s}$ a total of $1271400 \mathrm{~m}^{3}$ of groundwater was pumped during the pumping test. The exact quantity of pumped water from pumping station Klariči was measured in reservoir Sela, where water comes from pipes and is further distributed to users.

Due to storms during the rain events occasional electricity disturbances occurred, which can be seen also in the time series of electrical conductivity measurements, presented in Fig. 8.
Before the pumping test the water table in well B-10/06 was around $2 \mathrm{~m}$ a.s.l., which is typical of thesummer time. A diurnal tidal effect could be noticed in the graph in Fig. 8, with a fluctuation of approximately $10 \mathrm{~cm}$. In the Klariči pumping station general fluc-

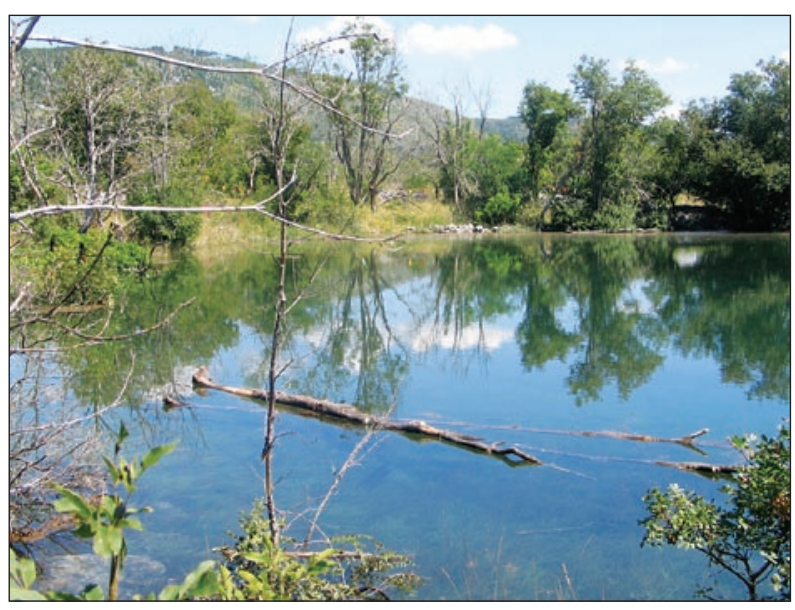

Fig. 7: Temporary lake originated by pumped groundwater (Photo: K. Mezga).

tuations of groundwater level after bigger storms could reach up to more than $6 \mathrm{~m}$. But after three storm events during the pumping test the karst ground water level in 
well B-10/06 rose by about $0.45 \mathrm{~m}$ in the well, which is less than $10 \%$ of maximum fluctuations. This suggests that the storm events during the pumping test had no bigger influence on the aquifer. Groundwater level in well B-10/06 decreased quickly, in 3-4 days, to the base flow level to approximately $1.65 \mathrm{~m}$ a.s.l. (Fig. 8).

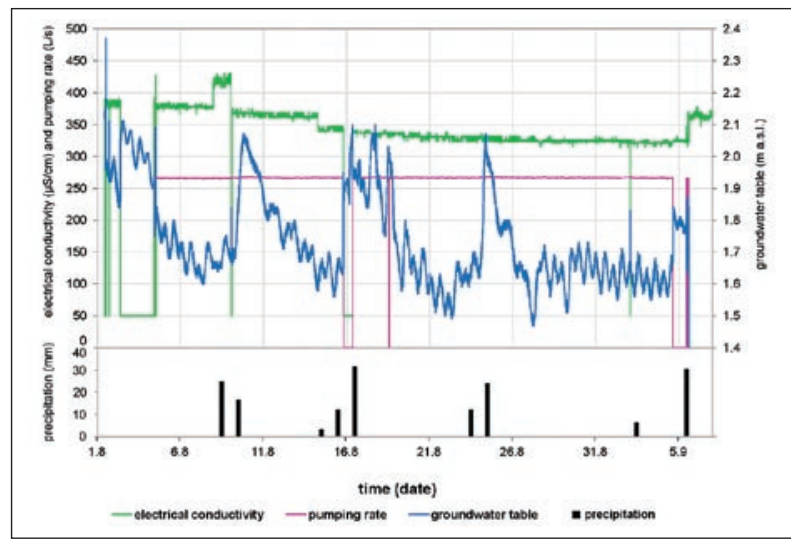

Fig. 8: Changes in electrical conductivity, pumping rate, groundwater table and amount of precipitation during the pumping test from well B-10/06.

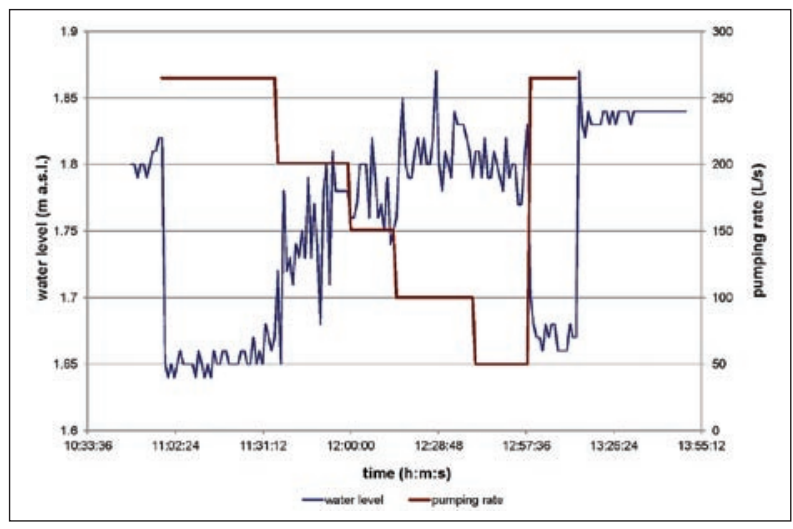

Fig. 9: Results of step-drawdown test in well B-10/06.

At the end of the pumping test (September the $5^{\text {th }}$ 2008) a step-drawdown test in well B-10/06 was performed (Fig. 9). During the step-drawdown test groundwater was pumped at different pumping rates, from 50 to $265 \mathrm{~L} / \mathrm{s}$.

As it can be seen from the step-drawdown test, the pumping of $265 \mathrm{~L} / \mathrm{s}$ caused a drawdown of only about $17 \mathrm{~cm}$ in well B-10/06. During full operation of all three pumping wells at the Klariči pumping station, the water table decreased only by approximately $70 \mathrm{~cm}$ at each well.

Changes in groundwater table at each specific pumping rate during step-test were assessed by data averaging. The tidal effect during the test was also consid- ered, groundwater level was increased by approximately $3 \mathrm{~cm}$ during the testing period.

Changes in groundwater level induced by different pumping rates are presented in Fig. 10. By $20 \%$ polynomial extrapolation data from Fig. 10 it can be concluded that at pumping rate of $320 \mathrm{~L} / \mathrm{s}$ the water table would decrease by only about $21 \mathrm{~cm}$.

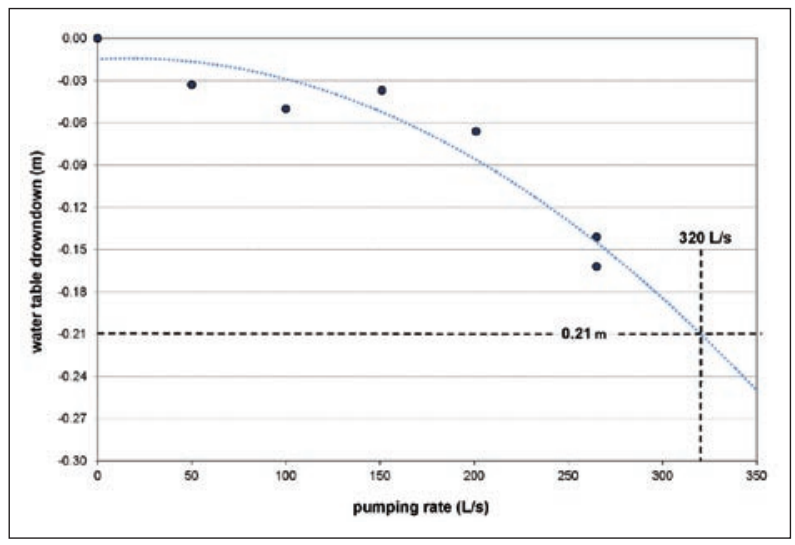

Fig. 10: Water table drawdown based on pumping rate in well B-10/06 during step-drawdown test.

Water table changes induced by step-test from well $\mathrm{B}-10 / 06$ were detected only in piezometers $\mathrm{Br}-1$ and $\mathrm{Br}-6$, where the former is located $9 \mathrm{~m}$ and the second $23 \mathrm{~m}$ away from $\mathrm{B}-10 / 06$. In piezometer $\mathrm{Br}-1$ the water table decreased by $8 \mathrm{~cm}$ and in piezometer $\mathrm{Br}-6$ by $4 \mathrm{~cm}$. Therefore the effective radius of the pumping well was estimated to be up to $23 \mathrm{~m}$. On the other observation piezometers, drawdown during the step-test was not detected.

Transmissivity of $1.34 \mathrm{~m}^{2} / \mathrm{s}$ was calculated on the basis of the well B-10/06 pumping test data. This result is by factor 15 greater than the transmissivity data obtained during the pumping test at the Klariči water supply wells in the year 1983 (Krivic et al. 1985).

The data presented suggests that quite large groundwater reserves exist in the karst aquifer. Due to the small decrease in water table in pumping wells and observation piezometers, it was assessed by the $20 \%$ data extrapolation, that the complete pumping facility Klariči could provide at least $560 \mathrm{~L} / \mathrm{s}$ of groundwater, even in the summer period. The pumping test results suggest also that only dynamic groundwater resources have been pumped. Pumping static groundwater reserves could be risky in terms of the seawater's possible intrusion into the karst aquifer.

\section{TRACER EXPERIMENT RESULTS}

The tracer test was carried out at the beginning of the pumping test on $4^{\text {th }}$ of August at 12:15. The injection point was located at the discharge of B-10/06 tempo- 
rary pipeline. The main goal of the tracer test was to determine whether the pumped water is returned to the pumping area. A further goal was to study the directions and the velocities of groundwater flow through the karst aquifer.

Tracer experiment results confirmed that the pumped groundwater was not returned to the exploitation wells during the pumping test, as no trace of uranine in the pumped groundwater was detected, neither by automatic fluorimeter measurements nor by laboratory analysis.

Uranine dye (Fig. 11) was detected only at Sardos Spring on $8^{\text {th }}$ of August at 23:28, i.e. 4 days, 11 hours and 13 minutes after the dye injection. Uranine was detected at a maximum concentration of $49.3 \mu \mathrm{g} / \mathrm{L}$ in the spring water by automatic fluorimeter. The occurrence of dye

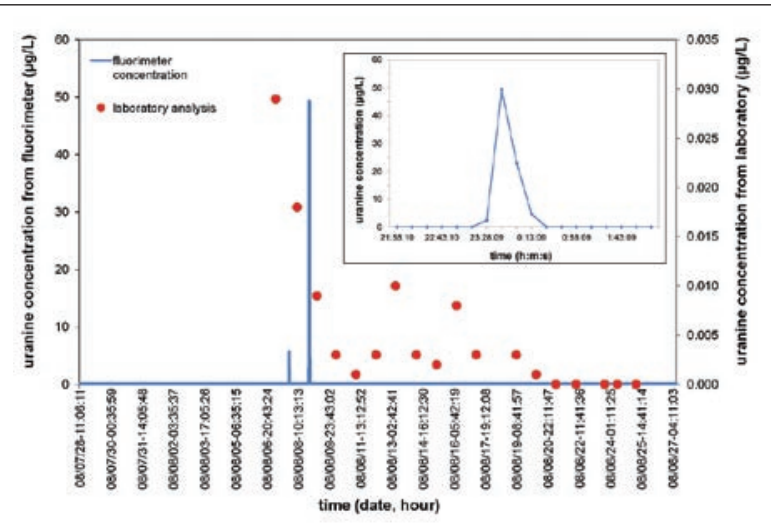

Fig. 11: Automatic fluorimeter and laboratory analysis tracer breakthrough curve for Sardos Spring for the pumping test period.

was also confirmed by laboratory analysis. Fluorimeter registered the dye incidence in the spring for about only one hour and was afterwards not detected by this device. Detailed laboratory analysis for fluorescent dye uranine showed that almost all measured values in the water samples were below limit of determination $(0.033 \mu \mathrm{g} / \mathrm{L})$, although some uranine traces above limit of detection $0.010 \mu \mathrm{g} / \mathrm{L}$ were measured in the water samples from Sardos Spring in the period between $7^{\text {th }}-15^{\text {th }}$ August.
Maximum uranine concentration of $0.029 \mu \mathrm{g} / \mathrm{L}$ was detected in the water sample of $7^{\text {th }}$ of August at 7:10 am.

The straight distance line between injection site and tracer detection location is $2,289 \mathrm{~m}$. Based on the breakthrough data of the tracer, the maximum linear groundwater flow velocity of $21.36 \mathrm{~m} / \mathrm{h}(512.5 \mathrm{~m} /$ day $)$ and the dominant linear flow velocity of $21.25 \mathrm{~m} / \mathrm{h}$ $(510 \mathrm{~m} /$ day) were calculated. Tracer recovery could not be calculated.

\section{CHEMICAL AND ISOTOPIC COMPOSITION OF SAMPLED WATER}

Groundwater from the karst aquifer (water samples from wells B-10/06 and B-9, and Timavo Spring) is of carbonate type with a $\mathrm{Ca}-\mathrm{HCO}_{3}$ hydrochemical facies. This water has a relatively high content of $\mathrm{HCO}_{3}^{-}$and a low content of $\mathrm{Mg}^{2+}$ which is typical of water originating from limestone. Water from the intergranular Soča River aquifer, on the other hand, has a hydrochemical facies of Ca- $\mathrm{Mg}-\mathrm{HCO}_{3}$, while its natural catchment area is the limestones and dolomites of Julian Alps.

Oxygen-18 content in the water from the karst aquifer suggests the origin of water from local precipitation in the Karst aquifer recharge area. The Soča River is depleted in oxygen-18, which is a consequence of meteoric waters falling at higher altitudes in the Julian Alps (Flora \& Longinelli 1989). Mean values of basic chemical parameters and oxygen-18 in the water for wells B-9 and B-10/06, the Soča River and the Timavo Spring are listed in Tab. 1.

Changes in the chemical and isotopic composition of groundwater during the pumping test were identified by water chemical analysis and automatic groundwater probes (Tab. 2). Electrical conductivity in groundwater from well B-10/06 decreased from $380 \mu \mathrm{S} / \mathrm{cm}$ to $325 \mu \mathrm{S} / \mathrm{cm}$. The overall decrease in electrical conductivity was also detected in exploitation wells at the pumping station Klariči, in well B-9, and in piezometers ( $\mathrm{Br}-3$, $\mathrm{Br}-4, \mathrm{Br}-5, \mathrm{Br}-6$ and $\mathrm{Br}-7)$. No indication of seawater intrusion to the karst aquifer during the pumping test was detected. Groundwater from well B-10/06 showed also a decrease in chemical parameters $\left(\mathrm{HCO}_{3}^{-}, \mathrm{Na}^{+}, \mathrm{Ca}^{2+}, \mathrm{Cl}^{-}\right.$ and $\left.\mathrm{SO}_{4}^{2-}\right)$, molar ratio $(\mathrm{Ca} / \mathrm{Mg})$ and depletion in isotope

Tab. 1: Mean values for each measured parameter in groundwater for wells B-9 and B-10/06, the Soča River and the Timavo Spring.

\begin{tabular}{l|c|c|c|c|c|c|c|c|c|c}
\hline Sampling point & $\mathrm{EC}$ & $\delta^{18} \mathrm{O}$ & $\mathrm{Ca}^{2+}$ & $\mathrm{Mg}^{2+}$ & $\mathrm{Na}^{+}$ & $\mathrm{K}^{+}$ & $\mathrm{HCO}_{3}^{-}$ & $\mathrm{Cl}^{-}$ & $\mathrm{NO}_{3}^{-}$ & $\mathrm{SO}_{4}^{2-}$ \\
\hline & $\mu \mathrm{S} / \mathrm{cm}\left(25^{\circ} \mathrm{C}\right)$ & $\% 0$ & $\mathrm{mg} / \mathrm{L}$ & $\mathrm{mg} / \mathrm{L}$ & $\mathrm{mg} / \mathrm{L}$ & $\mathrm{mg} / \mathrm{L}$ & $\mathrm{mg} / \mathrm{L}$ & $\mathrm{mg} \mathrm{N}-\mathrm{NO} / \mathrm{L}$ & $\mathrm{mg} / \mathrm{L}$ & $\mathrm{mg} / \mathrm{L}$ \\
\hline B-9 & 432.2 & -7.2 & 90.0 & 6.3 & 4.7 & 0.5 & 282.8 & 6.5 & 8.4 & 9.6 \\
\hline B-10/06 & 360.5 & -8.1 & 60.5 & 9.5 & 7.8 & 0.8 & 213.0 & 12.3 & 6.2 & 9.7 \\
\hline Soča River & 264.7 & -8.2 & 43.2 & 8.6 & 1.6 & 0.8 & 169.3 & 1.7 & 2.9 & 6.4 \\
\hline Timavo Spring & 399.0 & -7.6 & 76.7 & 7.3 & 5.2 & 0.8 & 249.8 & 7.7 & 7.0 & 9.6 \\
\hline
\end{tabular}


Tab. 2: Basic physical and chemical parameters measured in groundwater of wells B-9 and B-10/06, the Soča River and the Timavo Spring.

\begin{tabular}{|c|c|c|c|c|c|c|c|c|c|c|c|c|}
\hline \multirow{2}{*}{ Sampling point } & \multirow{2}{*}{ Date } & pH & $E C$ & $\delta^{18} 0$ & $\mathrm{Ca}^{2+}$ & $\mathrm{Mg}^{2+}$ & $\mathrm{Na}^{+}$ & $K^{+}$ & $\mathrm{HCO}_{3}^{-}$ & $\mathrm{Cl}^{-}$ & $\mathrm{NO}_{3}^{-}$ & $\mathrm{SO}_{4}^{2-}$ \\
\hline & & $\left(25^{\circ} \mathrm{C}\right)$ & $\mu \mathrm{S} / \mathrm{cm}\left(25^{\circ} \mathrm{C}\right)$ & $\% 0$ & $\mathrm{mg} / \mathrm{L}$ & $\mathrm{mg} / \mathrm{L}$ & $\mathrm{mg} / \mathrm{L}$ & $\mathrm{mg} / \mathrm{L}$ & $\mathrm{mg} / \mathrm{L}$ & $\mathrm{mg} / \mathrm{L}$ & $m g N-\mathrm{NO}_{3}^{-} / \mathrm{L}$ & $\mathrm{mg} / \mathrm{L}$ \\
\hline B-9 & 2008-08-06 & 7.36 & 443 & -6.99 & 94 & 5.7 & 4.3 & 0.43 & 287 & 5.63 & 7.52 & 9.28 \\
\hline B-9 & $2008-08-11$ & 7.39 & 426 & -7.19 & 90 & 6.1 & 4.6 & 0.51 & 276 & 6.18 & 8.41 & 9.62 \\
\hline B-9 & $2008-08-18$ & 7.30 & 435 & -7.10 & 89 & 6.4 & 4.6 & 0.53 & 284 & 6.35 & 8.27 & 9.65 \\
\hline B-9 & $2008-08-22$ & 7.39 & 426 & -7.32 & 89 & 6.1 & 4.5 & 0.49 & 279 & 6.38 & 8.49 & 9.66 \\
\hline B-9 & 2008-08-29 & 7.25 & 405 & -7.29 & 88 & 6.7 & 4.9 & 0.54 & 287 & 7.17 & 8.94 & 9.68 \\
\hline B-9 & 2008-09-02 & 7.26 & 458 & -7.31 & 90 & 6.5 & 5.0 & 0.51 & 284 & 7.16 & 8.89 & 9.73 \\
\hline B-10/06 & 2008-08-06 & 7.56 & 374 & -7.89 & 64 & 9.7 & 8.8 & 0.81 & 228 & 14.10 & 6.28 & 9.86 \\
\hline B-10/06 & 2008-08-11 & 7.63 & 365 & -8.05 & 62 & 9.5 & 7.8 & 0.77 & 215 & 12.40 & 6.28 & 9.71 \\
\hline B-10/06 & 2008-08-18 & 7.52 & 366 & -8.09 & 61 & 9.4 & 7.6 & 0.75 & 207 & 12.30 & 6.19 & 9.81 \\
\hline B-10/06 & $2008-08-22$ & 7.62 & 359 & -8.04 & 59 & 9.5 & 7.8 & 0.76 & 214 & 12.50 & 6.15 & 9.82 \\
\hline B-10/06 & 2008-08-29 & 7.55 & 329 & -8.15 & 59 & 9.5 & 7.4 & 0.80 & 207 & 11.50 & 6.19 & 9.48 \\
\hline B-10/06 & 2008-09-02 & 7.52 & 370 & -8.15 & 58 & 9.4 & 7.1 & 0.80 & 207 & 11.20 & 6.19 & 9.24 \\
\hline SočaRiver & 2008-08-06 & 8.27 & 272 & -8.26 & 46 & 9.1 & 1.8 & 0.53 & 176 & 1.90 & 3.05 & 5.97 \\
\hline SočaRiver & 2008-08-11 & 8.36 & 279 & -8.25 & 45 & 9.8 & 1.8 & 0.48 & 179 & 1.92 & 2.96 & 8.93 \\
\hline SočaRiver & 2008-08-18 & 8.20 & 257 & -8.23 & 42 & 8.2 & 1.4 & 0.47 & 160 & 1.42 & 2.83 & 6.25 \\
\hline SočaRiver & 2008-08-22 & 8.18 & 254 & -8.01 & 41 & 8.3 & 1.4 & 0.42 & 163 & 1.59 & 2.74 & 5.32 \\
\hline SočaRiver & $2008-08-29$ & 8.15 & 246 & -8.15 & 42 & 7.7 & 1.4 & 0.47 & 170 & 1.43 & 2.78 & 5.94 \\
\hline SočaRiver & 2008-09-02 & 8.22 & 280 & -8.21 & 43 & 8.3 & 1.8 & 0.58 & 168 & 1.89 & 2.96 & 6.17 \\
\hline Timavo Spring & 2008-08-06 & 7.38 & 405 & -7.42 & 80 & 7.2 & 5.2 & 0.82 & 251 & 7.54 & 7.08 & 9.37 \\
\hline Timavo Spring & 2008-08-11 & 7.39 & 410 & -7.71 & 81 & 6.9 & 5.2 & 0.79 & 256 & 7.66 & 7.03 & 9.45 \\
\hline Timavo Spring & 2008-08-18 & 7.35 & 413 & -7.55 & 78 & 7.1 & 5.2 & 0.77 & 257 & 7.74 & 7.03 & 9.59 \\
\hline Timavo Spring & $2008-08-22$ & 7.42 & 395 & -7.72 & 75 & 7.6 & 5.3 & 0.87 & 246 & 7.93 & 7.12 & 9.69 \\
\hline Timavo Spring & 2008-08-29 & 7.39 & 362 & -7.65 & 73 & 7.4 & 5.3 & 0.88 & 248 & 7.68 & 6.90 & 9.66 \\
\hline Timavo Spring & $2008-09-02$ & 7.38 & 409 & -7.28 & 73 & 7.6 & 5.1 & 0.85 & 241 & 7.39 & 6.99 & 9.60 \\
\hline
\end{tabular}

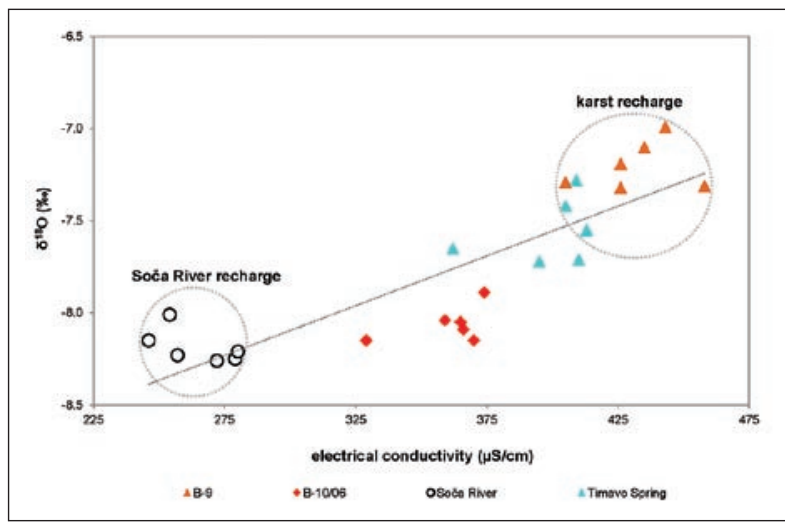

Fig. 12: Water electrical conductivity in relation to oxygen isotope composition.

oxygen - 18 content in the water. These observations suggest that during intense pumping the chemical composition of karst groundwater is progressively shifted towards the Soča River water composition. Water from the inter- granular Soča River aquifer and karst aquifer was mixed in the area of pumping station Klariči.

The comparison between oxygen-18 composition of water and its electrical conductivity is presented in Fig. 12. All samples lie almost on a straight line which is interpreted as a mixing line between karst recharge and the Soča River aquifer end members. With pumping duration, the $\delta^{18} \mathrm{O}$ isotope composition of groundwater from well B-10/06 changes towards the Soča River water composition. Samples with higher electrical conductivity are also enriched in the heavy oxygen isotope. We can conclude from the graph that the Timavo Spring isotope and chemical characteristics are more similar to karst recharge. It has been already proven (Flora \& Longinelli 1989) that the Timavo Spring is a mixture of two major components, water derived from the Reka River and local precipitation, while the Soča River water presents a minor component. 
Assuming the mean $\delta^{18} \mathrm{O}$ value of the Soča River water being $-8.18 \%$, the mean $\delta^{18} \mathrm{O}$ value of the karst aquifer Brestovica -7.2\%o (well B-9), and the mean $\delta^{18} \mathrm{O}$ value of B-10/06 $-8.06 \%$, the proportion of the Soča River in groundwater pumped can be assessed. The simple two-component mixing equation was used:

$\mathrm{F}_{\text {Soča }}=\frac{\left(\delta_{\text {pumped }}-\delta_{\text {karst }}\right)}{\left(\delta_{\text {Soča }}-\delta_{\text {karst }}\right)}$

$\mathrm{F}_{\text {Soča }}-$ fraction of the Soča River water

$\delta_{\text {karst }}-\delta^{18} \mathrm{O}$ of karst water component

$\delta_{\text {pumped }}-\delta^{18} \mathrm{O}$ of water pumped from well B-10/06

$\delta_{\text {Soča }}-\delta^{18} \mathrm{O}$ of Soča River water

The water component from the Soča River aquifer was estimated at about $88 \%$ during the final phase of intense pumping test in well B-10/09.

Fig. 13 presents changes in $\mathrm{HCO}_{3}^{-}$and $\mathrm{Ca} / \mathrm{Mg}$ molar ratio in groundwater from well B-10/06 during the pumping test. Fig. 14 presents changes in chloride

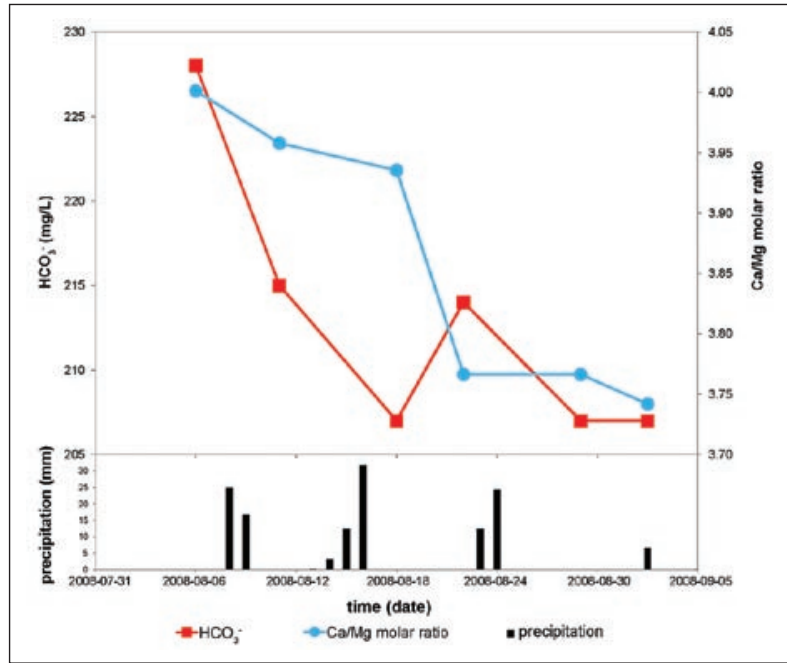

Fig. 13: Changes in $\mathrm{HCO}_{3}^{-}$and $\mathrm{Ca} / \mathrm{Mg}$ molar ratio in groundwater from well B-10/06 during the pumping test. and $\delta^{18} \mathrm{O}$ in groundwater from well $\mathrm{B}-10 / 06$ during the pumping test. The content of those parameters decreased due to the Soča River water inflow.

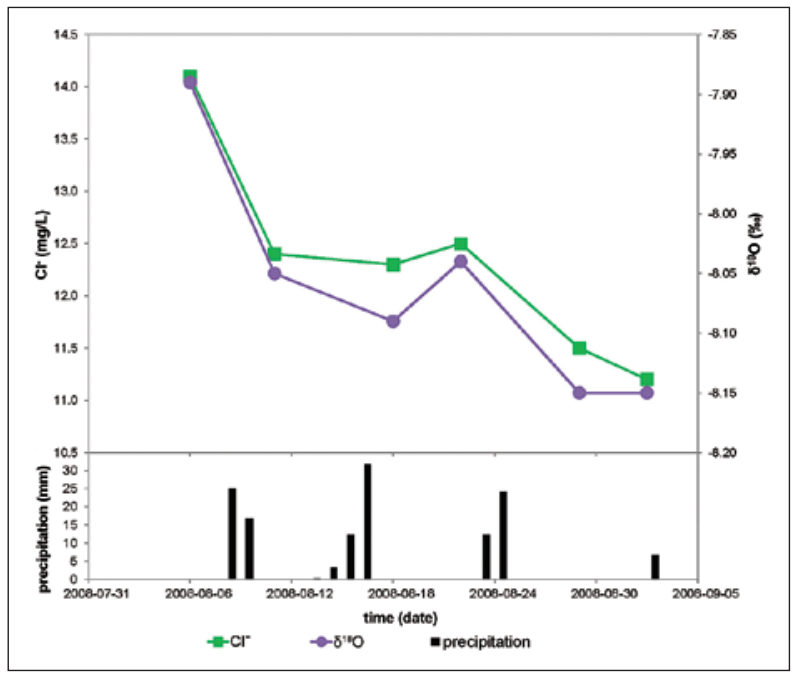

Fig. 14: Changes in chloride and $\delta^{18} \mathrm{O}$ in groundwater from well B-10/06 during the pumping test.

Doctor et al. (2006) and Gemiti (2011) linked the source of chloride concentration to anthropogenic components leeching into the local shallow vadose-zone circulation. Another explanation could also be the influence of the Adriatic seawater, either direct past or present influence of seawater to the karst aquifer (Gemiti 2011) or indirect due to sea spray transferred by stronger winds. Further research needs to be done regarding this matter.

Groundwater samples taken during pumping test from well B-10/06 showed that none of the chemical parameters exceeds the threshold values of Rules on drinking water (Pravilnik o pitni vodi 2004). All pesticides are below detection level and nitrate level is $6.5 \mathrm{mg} \mathrm{NO}_{3}^{-} / \mathrm{L}$ (expressed as $\mathrm{N}-\mathrm{NO}_{3}$ ). Groundwater does not meet the drinking water quality standards for bacteriological parameters, which is quite usual for karst aquifers; therefore the water needs to be disinfected for further use.

\section{CONCLUSIONS}

The aim of the pumping experiment was to assess the capacity of Brestovica karst aquifer in the area of Klariči pumping station. On the basis of one month's simultaneous pumping of $470 \mathrm{~L} / \mathrm{s}$ of groundwater from four wells at pumping station Klariči during the summer period, the capacity of the karst aquifer Brestovica at Klariči was evaluated. During the pumping test the water table in wells at pumping station Klariči decreased by about $70 \mathrm{~cm}$ and in well B-10/06 by $17 \mathrm{~cm}$. Based on obtained data, a conclusion was made that a greater quantity of groundwater could be pumped from these wells. By extrapolating the common pumping capacity by $20 \%$, the 
assessed capacity of the karst aquifer at Klariči during the summer period is $564 \mathrm{~L} / \mathrm{s}$ at drawdown of about $21 \mathrm{~cm}$ in well B-10/06. Since the pumping test data indicate quite larger groundwater reserves, there exists a possibility of more intensive groundwater exploitation. Krivic (1983) estimated that even approximately 1,000 L/s of groundwater could be pumped from this karst aquifer.

No significant negative effect on groundwater level due to constant pumping from all four wells was detected during the pumping experiment. Also no negative effect on the chemical composition and quality of groundwater was detected.

The data obtained suggests that the karst aquifer has complementary recharge during dry periods. Intense pumping during summer meteorological conditions increased the inflow of water from the Soča River aquifer into the karst aquifer, which was detected by changes in chemical and isotopic composition of groundwater. Hydrochemical parameters in conjunction with the stable isotope data was proved to be a very useful tool for track- ing the origin and mixing source components in a karst aquifer. Water pumped from well B-10/06 showed appropriate chemical composition for the purpose of water supply, but needs to be disinfected for further use.

Dye tracing at the outflow of temporary pipeline enables the assessment of groundwater flow velocity, which is around $510 \mathrm{~m} /$ day between Klariči and Sardos Spring.

The research upgraded the already existing knowledge on the Classical Karst aquifer Brestovica. The pumping experiment was quite demanding, as it required a lot of organisation work, investment in the equipment and electrical energy and a lot of expert work. By successfully performed pumping experiment the pumping capacity from a new well B-10/06 together with the existing Klariči pumping station capacity has been proven. This pumping experiment is of vital importance also for the Slovenian Coastal area water supply strategy. It proved that additional drinking water quantities exist in the Slovenian Classical Karst area, which could be exploited in the future.

\section{ACKNOWLEDGEMENTS}

We would like to thank the Ministry of the Environmental and Spatial Planning for financing the pumping test. Furthermore we would like to thank the Water Supply Kraški vodovod Sežana (Slovenia), the Department of Geosciences at the University of Trieste (Italy) and the
Water supply company Azienda Comunale Elettricità Gas ed Acqua (ACEGA) from Trieste (Italy) for help in organizing the pumping test, tracer test, and in water sampling during the experiment.

\section{REFERENCES}

Azienda Comunale Elettricità Gas ed Acqua (ACEGA) Trieste, 1988: Il problema dell'acqua nella provincia di Trieste.- Arti Grafiche Smolars s.p.a, pp. 28, Trieste.

Bat, M., Dolinar, M., Frantar, P., Hrvatin, M., Kobold, M., Kurnik, B., Nadbah, M., Ožura, V., Uhan, J. \& F. Ulaga, 2008: Vodna bilanca Slovenije 1971-2000 (Water Balance of Slovenia 1971-2000).- Ministry of the Environment and Spatial Planning, Environmental Agency of the Republic of Slovenia, pp. 119, Ljubljana.

Bidovec, F., 1967: The hydrosystem of karstic springs in the Timavo basin.- Hydrology of fractured Rocks, $1,263-274$.

Boegan, E., 1938: Il Timavo. Studio sull'idrografia carsica subaerea e sotterranea.- Memoria II, Istituto Italiano di Speleologia, serie Geologica e Geofisica, pp. 251, Trieste.
Carulli, G.B., 2011: Structural model of the Trieste Gulf: A proposal.- Journal of Geodynamics, 51, 156-165.

Cività, M., Cucchi, F., Eusebio, A., Garavoglia, S., Maranzana, F. \& B. Vigna, 1995: The Timavo Spring Hydrogeologic system: An important reservoir of supplementary water resources to be reclaimed and protected.- Acta Carsologica, 24, 169-186.

Cucchi, F. \& L. Zini, 2002a: Considerations on the speleogenesis in the Trieste Classical Karst.- Memorie Società Geologica Italiana, 57, 481-486.

Cucchi, F. \& L. Zini, 2002b: Underground Timavo River monitoring (Classical Karst).- Acta Carsologica, 31, $1,75-84$. 
Doctor, D.H., Lojen, S. \& M. Horvat, 2000: A stable isotope investigation of the Classical Karst aquifer: evaluating karst groundwater components for water quality preservation.- Acta Carsologica, 29, 1, 79-82.

Doctor, D.H., Alexander, E.C. Jr., M. Petrič, Kogovšek, J., Urbanc, J., Lojen, S. \& Stichler, W., 2006: Quantification of karst aquifer discharge components during storm events through end-member mixing analysis using natural chemistry and stable isotopes as tracers.- Hydrogeology Journal, 14, 1171-1191.

Doctor, D.H., 2008: Hydrologic connections and dynamics of water movement in the Classical Karst (Kras) aquifer: evidence from frequent chemical and stable isotope sampling.- Acta Carsologica, 37, 1, 101-123.

Flora, O. \& A. Longinelli, 1989: Stable isotope hydrology of classical karst area, Trieste, Italy.- In: International Atomic Energy Agency (IAEA)Isotope techniques in the study of the hydrology of fractured and fissured rocks, Panel Proceedings Series, $17^{\text {th }}-21^{\text {th }}$ November 1986, Vienna. International Atomic Energy Agency (IAEA), 203-213, Vienna.

Gemiti, F., 2011: Origine e bilancio dei cloruri nelle acque del Carso Classico.- Atti e Memorie della Commissione Grotte »Eugenio Boegan«, 43, 117-149.

Jurkovšek, B., 2008: Geološka karta severnega dela Tržaško-komenske planote 1:25 000 (Geological Map of the Northern Part of the Trieste-Komen Plateau 1:25 000), 1:25 000.- Geological Survey of Slovenia, Ljubljana.

Jurkovšek, B., 2010: Geološka karta severnega dela Tržaško-komenske planote 1:25 000: tolmač (Geological Map of the Northern Part of the Trieste-Komen Plateau 1:25 000: Explanatory book).- Geological Survey of Slovenia, pp. 72, Ljubljana.

Katz, B.G., 1998: Using $\delta^{18} \mathrm{O}$ and $\delta \mathrm{D}$ to Quantify Ground-Water/Surface-Water Interactions in Karst Systems of Florida.- In: U.S. Environmental Protection Agency (eds.) Proceedings of the National Water Quality Monitoring Conference, Monitoring: Critical Foundations to Protect Our Waters, $7^{\text {th }}-9^{\text {th }}$ July 1998, Reno, Nevada. U.S. Environmental Protection Agency, 195-208, Washington, D.C.

Kristan, S. \& P. Skrinjar, 1998: Kraški vodovod Sežana 1948-1998: 50 let.- Water supply company Kraški vodovod Sežana, pp. 32, Sežana.

Krivic, P., 1983: Interprétation des essais par pompage réalisés dans un aquifère karstique (Obdelava črpalnih poizkusov v kraškem vodonosniku).- Geologija, 26, 149-186.

Krivic, P., Juren A. \& M. Bizjak, 1985: Poročilo o hidrološki spremljavi končnega črpalnega poizkusa na črpališču $v$ Klaričih pri Brestovici.- Geological Survey of Slovenia, Report No. K-II-30d/c-1/550, Ljubljana.
Krivic, P., Drobne, F., Juren, A., Kokol, L., Strojan, M. \& B. Ravnikar, 1986: Letno poročilo 1986. Pitne, tehnološke in mineralne vode. Hidrogeološke raziskave vodnih virov $v$ karbonatnih kamninah. Letno poročilo hidrogeološke raziskave zaledja vodnih virov pri Klaričih.- Gelogical Survey of Slovenia, Report No. 2956, Ljubljana.

Mosetti, F. \& C. D’Ambrosi, 1963: Alcune ricerche preliminari in merito a supposti legami di alimentazione fra il Timavo e l'Isonzo (Some preliminary research regarding the connection of supply between the Timavo and the Isonzo).- Bollettino di Geofisica Teorica ed Applicata, 5, 17, 69-83.

Pezdič, J., Dolenc, T., Krivic, P. \& J. Urbanc, 1986: Environmental Isotope Studies Related to Groundwater Flow in the Central Slovenian Karst Region, Yugoslavia.- In: Morfis, A. \& P. Paraskevopoulou (eds.) $5^{\text {th }}$ International symposium on underground water tracing, 22 ${ }^{\text {th }}-27^{\text {th }}$ September 1986, Athens, Greece. The Institute of geology and mineral exploration, The International working group on tracer methods in hydrology, 91-100, Athens.

Pravilnik o pitni vodi, 2004: Uradni list Republike Slovenije 19/2004 (z dopolnitvami). Ljubljana.

Prestor, J. \& M. Janža, 2006: Ocena višine infiltracije (po metodi Kennessy) in ranljivost podzemne vode na območju Slovenije.- Geological Survey of Slovenia, Report No. K-II-30d/c-4/1356-c, Ljubljana.

Ravbar, N., 2004: Drinking water supply from Karst water resources (the example of the Kras plateau, SW Slovenia).- Acta Carsologica, 33, 1, 5, 73-84.

Urbanc, J. \& S. Kristan, 1998: Isotope investigation of the Brestovica water source during an intensive pumping test.- RMZ - Materials and Geoenvironment, 45, 1-2, 187-191.

Urbanc, J., Bizjak, M., Medić, M., Hötzl, M., Matoz, T. \& J. Herič, 2007: Ugotavljanje kapacitete vodnega vira Brestovica.- Geological Survey of Slovenia, Report No. K-II-30d/c-4/1186-c, Ljubljana.

Urbanc, J., Mezga, K., Bizjak, M., Medić M., Hötzl M. \& J. Herič, 2008: Hidrogeološka spremljava črpalnega poizkusa za ugotavljanje kapacitete vodnega vira Brestovica.- Geological Survey of Slovenia, Report No. K-II-30d/c-2/1185-a, Ljubljana.

Zini, L., Calligaris, C., Treu, F., Iervolino, D. \& Lippi, F., 2011: Risorse idriche sotterranee del Friuli Venezia Giulia: sostenibilità dell'attuale utilizzo.- Regione Autonoma Friuli Venezia Giulia and Università degli Studi di Trieste-Dipartimento di Geoscienze, pp. 89 , Trieste. 